\title{
Politics in Kajaolaliddong's Pappaseng: Representation of Buginese Local Wisdom
}

\author{
Muhammad Bahar Akkase Teng ${ }^{1}$, Andi Faisal ${ }^{2}$, Firman Saleh ${ }^{3}$ \\ \{bahar.akase@unhas.ac.id/baharakkase@gmail.com \\ afaisal@unhas.ac.id/andifaisal.prancis.unhas@gmail.com² \\ fiermansaleh@yahoo.com ${ }^{3}$ \} \\ Faculty of Cultural Sciences Hasanuddin University \\ J1. Perintis Kemerdekaan Km. 10, Tamalanrea, Makassar
}

\begin{abstract}
This study describes Kajaolaliddong political thinking in Kajaolaliddong's Pappaseng (messages) as democratic representation of Buginese Society's local wisdom which is highly upheld as an order and guide in carrying out state and social activities. The study was descriptive qualitative using observation and library research. The data was analyzed by using structural analysis. The result of the study indicates that politic and democratic values in Kajaolaliddong's Pappaseng is used as a reference in politic applied in Buginese society and human rights. The representation of democratic values can be inherited to young generation in developing the democracy and sound and dignified knowledge of democracy. Kajaolaliddong Pappaseng teaches political attitude in dignified, responsible, and reliable democracy.
\end{abstract}

Keywords: Politics, Kajaolaliddong's Pappaseng, local wisdom

\section{Introduction}

Politics as a behavior and a way to common happiness often becomes a reference in contemporary political thinking. This paradigm reflects how to manage government and becomes an ethical source in carrying out practical politic in modern society especially in western society [1]. As for the traditional cultural society particularly in Buginese society, the management of state and social affairs have been practiced in daily life of the society including its political life. Political thinking and Kajaolaliddong democracy is an example of how political practice has been done for a long time and is respected and upheld by the Buginese society. Kajaolaliddong's political and democratic thinking in the form of Pappaseng (messages) contains ideal democratic values as in the conception and values of modern democracy.

Pappaseng contains will, advice, messages about political system and social affairs. The messages and advice are not only focused on the king, but also on the people through dialog between Arung (king or adat leader) and Kajaolaliddong. In the dialog Kajaolaliddong or also often named La Mellong includes the values and characteristics that must be possessed by a king and the people: lempu' (honesty), acca (intelligence), asitinajang (appropriateness), getteng (perseverance), reso (effort, hard work), and siri' (dignity) [2], [3], [4]. 
In the governance of Buginese society, the existence of the king's power has been limited in the Law or it is usually termed as getting bicara. In getting bicara there is a guide for the king as a tool to act according to the norms based on adat istiadat (pangngadereng) "tradition" that a king must put everything according to its portion [2]. This is stated in the next sentence: "I use my measurement to measure, my weight to weigh, the low I put underneath, the middle I put in the middle, the high I put above". This paper explains comprehensively the political concept of Kajaolaliddong as realization and representation of local wisdom in carrying out state and social affairs (democracy).

\section{Research Method}

This study is descriptive qualitative using observation [5] and library research applying structural analysis. The study reveals that democratic values in Kajaolaliddong's pappaseng as a reference in political affairs which is applied in Buginese society and the values of human rights.

\section{Result and Discussion}

Kajaolalidong's thinking about justice and governance is regarded as sufficient in explaining the reason and government political morality. Even the poet W.S. Rendra whose nick name the peacock said that the Kajaolaliddong's thinking preceded "Napoleon Code". Kajaolaliddong or La Mellong was appointed as an advisor and lived with several Arumpone (title for Bone king) for the time of La Tenri Rawe BongkangE. In the course of La Tenri BongkangE government, the kingdom of Bone was in gloriousness. This is inseparable from the thinking of Kajaolaliddong in developing economic, politics, military and external relations of Bone kingdom [2].

In government and Bone kingdom, the one who would be appointed to be king should have some requirements to fulfill: noble descendant, honest, skillful in governing the people, and wealthy. All these are very beneficial in doing the task as a leader/king.

One who was appointed a king was meant to fulfill the hopes of the people that is to protect and to take care of them. Based on the tradition which was effective since the government of Petta Manurungnge ri Matajang, the first who made social contract between a leader and his people said that "We appointed you as a king to take care of us" [6]. Government contact between a king and his people is a source of modern democratic values in which the king as representation of the highest sovereignty should listen and consider the voice of the people and was not absolute in carrying out the government as also has been put forward by J.J. Rousseau about social contract [7] as a social agreement between the government and the people in the form of state and management of the government.

\subsection{Kingdom Democratic Values}

Through the government of La Tenri Rawe BongkangE, the kingdom developed very rapidly both in government and the society. The development was inseparable from the attitude of La Tenri BongkangE who liked to listen to the complaints and advice of the people 
especially the advice from Kajaolaliddong as an advisor of the kingdom at that time. The following is the dialog between Kajaolaliddong and Arumpone reflecting how a kingdom exists and falls.

\begin{abstract}
Makkadae Arumpone: Aga tanra cinna matena tana marajae, Kajao?
(Arumpone asked: "What is the sign of the fall of a great nation, Kajao?")

Makkadae Kajaolaliddong: Iyana tanra cinna matena tana marajae, Arumpone linga-lingae, maduanna nakko teyai ripakainge Arunge, metalunna: dek-e tomacca ri wanuwae, maeppakna, nokkok naenrekiwi warang(m)parang tomabbicarae; malimanna, weddok pada-gauk rilaleng(m)panuwa; maennenna, tennamasewi atanna arung-mangkauke". (Kajaolaliddong said: As for the sign of the fall of a great nation, Arumpone: first, ignorance; second, if the king won't listen to advice or warning; third, when there is no more intellectual in the country; fourth, if pabbicara (law enforcer) receives gravitation; fifth, evil deeds and violence are rampant in the country; sixth, when the king no longer loves his people.)"
\end{abstract}

Makkadae Arumpone: Aga tanranna, namaraja tana-e, Kajao?

(Arumpone asked: What is the sign of a great nation, Kajao?)"

Makkadae Kajaolaliddong: Duwa tannranna, namaraja tana-e, Arumpone, Seuwwani, melempu-I na macca arung-mangkauk-e; maduwanna, tessisala-salae ri laleng $(\mathrm{m})$ panuwa. (Kajaolaliddong replied: there are two signs to make a country great, Arungpone. First, if Arung Mangkauk is honest and smart; second, there is no dispute in the country)".

Makkadae Arumpone: Aga tula-pattaungeng, Kajao?"

(Arumpone asked: What is the cause of annual disaster, Kajao?"

Makkadae Kajaolaliddong: Naiya tulae pattaungeng, Arumpone, seuwani, nakkomatanre cinnai arung-mangkauk-e; maduwanna, rekkonateriwi warang(m)parang to mabbicarae: matellunna, nakko sisala-salai tauwe ri allempanuwa; tanranna taparo, nakko maelonkni baiccu tanae marajae".

(Kajaolaliddong replied: first, if the will of Arung Mangkauk is very great; second, receiving a gift from people who are in cases; third, quarreling with people in the country are the signs of a great country to be small) [8].

The dialog illustrates how a king with all his greatness and power would like to listen to advice and consideration from Kajaolaliddong as his subordinate (his people). One who would be a king should understand that the king functions as the people attendant and the king should take care of the people as it is expressed in the proverb below:
"Muampirikkeng temmakare'
Modoringirikkong temmatippe
Musalipurikkeng temmadinging"

(The people give themselves to the king to be with the hope that the king can take care of them) [6]. 
The relationship between the king and the people has been lasted and been effective since Petta Manurungnge ri Matajang led the kingdom of Bone until King VIII was assumed to be able to understand and take care of the people. The kingdom of Bone reached its glory because the king was consistent to take care of the welfare of his people.

One of the kings of Bone, namely, La Tenri Rawe BongkangE, king of Bone VII got a strategic place in the life of the society and state affairs as it was expressed in Lontara tradition which was quoted as follows:

"Rusa Taro Arung, tenrusa taro ade,

Rusa taro ade, tenrusa taro anang,

Rusa taro anang, tenrusa taro tomaega"

(King's resolution can be cancelled, but adat resolution cannot

Adat resolution can be cancelled, but group resolution cannot

Group resolution can be cancelled, but the people resolution cannot)

The expressions above illustrate how satisfaction of "tomaega" (the people/people resolution) becomes the highest voice in making a decision even it is assumed to subdue or cancel the king's decision. The voice of the people becomes the characteristic of modern democracy as the characteristic of people government itself as it is reflected in the expression "from the people, by the people, and for the people". From the explanation and the expression, it is clear that the position of the people is very central in the social life and state affairs even it becomes determinant in important decision making.

It is mentioned in Lontara that the obligation of Arung Matowa is as follows:

Uselimpuremmu temmacekke,

Udongirimmu temmatippa,

Utanrereangekko asalangmu,

Ualangekko atongemmu [9].

"(I put blanket on you to be free from cold (free from danger and difficulty, You are awake like a sparrow so the rice is not empty (the king takes cares of the people and their property,

I deny mistakes (the king listens to all complaints of his people, I defend for your truth)"

There was a violation after the king VIII. A king had violated agreements fixed before he became a king. He was the king of Bone, La Inca' Matinroe ri Addengna, who substituted his brother, La Tenri Rawe BongkangE MatinroE ri Gucinna.

When he resigned as king on the agreement of Matowa Pitue (Adat Council 7), La Tenri Rawe BongkangE MatinroE ri Gucinna said:

"You La Inca, whom I hope to continue and upholding the trust of the people to carry out your duty properly. As the addition, when my burial is over, tie a knot with your sister in law (meaning MatinroE ri Gicinna's wife named We Tenri Pakiu Arung Timurung) because she is a woman who has a lot of advantages in government" [6]. 
When the people noticed that Arumpone La Inca' violated the agreement in carrying out the government task and acted arbitrarily, the people complained and reported it to Arung Majang (a noble and a grandfather of La Inca'). He said to his grandson: "Tania Iko lebbi na to MaegaE" which means you are not more valuable than the people. From the expression, people did not know that Arumpone La Inca' had been dethroned as a king since he was no longer paid attention to nor took care of the people as had been done by previous kings.

The position and respect of the people in state affairs is very vital knowing that the people position is assumed as the highest sovereignty of all. The position of a king is only as the representation of responsibility in the management of government given by the people. The relationship between the king and the people is government contract in which the king was given a mandate by the people to serve and take care of them in one side and the people must respect and obey the king on the other side, provided it is not contrary to grand values of adat istiadat (tradition) respected together by the king and the people. The policy of social contract done between Manurungnge ri Matajang and with the people of Bone is an agreement contains an ideal democratic element.

The other description illustrates how democracy was applied based on the voice of the people can be seen in the conversation between La Tenri Ruwa Sultan Adam MatinroE ri Bantaeng and Adat Council. La Tenri Ruwa Sultan Adam MatinroE ri Bantaeng said to Ade' PituE (Adat Council) that "According to our agreement (Bone) and Gowa, whoever sees goodness then he should tell it to other kings. Now Gowa came to bring Islam to us [6]. The statement was not accepted by Ade'PituE (Adat Council7). Since it was not accepted, La tenri Ruwa left the kingdom to Pattiro. After the arrival at Pattiro, La Tenri Ruwa was also rejected because he embraced Islam and the people did not like to follow him. At last the king left for Bantaeng snd died there so that he was given a title La Tenri Ruwa Sultan Adam MatinroE ri Bantaeng" [6].

The other democratic value develops in Buginese society is the agreement causing the existence of Buginese cultural values called Uluada. Uluada contains agreement or pledge having a very important aim for the kingdom to make an agreement between two parties. The pledge was based on agreement to tie friendship between kingdoms which must be obeyed by both kingdoms. When violation occurs, the sanction was very severe for the violator not only those who involved at that time, but also their children and grandchildren of both parties. The two parties should obey it in the time to come.

The value of agreement which was based on fidelity becomes the substance of a relationship. The relation which is not only advantageous for both parties, but also as a tie and motivator for the continuity of democratic life in the future. This puts more emphasis on what Alain Badiou (2004) called "fidelity to the moment of truth" [10] which has been lost in the life of modern democracy when political and democratic life is no longer based on the truth values but on transactional politic for pragmatic interest only. Kajaolaliddong's political and democratic thinking is relevant to interrogate contemporary political thinking practices which increasingly become the voice of the people themselves. Although the voice of the people is mentioned, it is merely political jargons.

\section{Conclusion}

In the dialog between Arung and Kajaolaliddong, Kajaolaliddong tries to inse rt values or characteristics which should be possessed by a king and his people that is lempu (honesty), 
acca (intelligence), asitinajang (appropriateness), getteng (perseverance), reso (effort, hard work), and siri (dignity).

The representation of democratic values is inherited to young generation in developing democracy to society and government to realize sound and dignified knowledge of democracy. Kajaolaliddong's Pappaseng teaches us political attitude in dignified, responsible and reliable democracy.

\section{References}

[1] Aristoteles, Nichomahean Ethics. Indianapolis: Hackett Publishing Company (1985)

[2] Teng M. B. A.: Falsafah Orang Bugis: Studi tentang Kajaolaliddong di Kabupaten Bone, (The Philosophy of Buginese: A Study of Kajaolaliddong in Bone Regency), Dissertation. Makassar: UIN Alauddin Makassar. pp. 3-5 (2009)

[3] Mattulada L: Suatu Lukisan Analisis Terhadap Antropologi Politik Orang Bugis. (Latoa: An Analysis of Political Anthropology of Buginese). Gajah Mada University Press (1985)

[4] Rahim R.: Nilai-nilai Utama Kebudayaan Bugis (The Main Values of Buginese Culture). Hasanuddin University Press, 1985.

[5] Kadir A.: Dasar-Dasar Metodologi Penelitian Kuantitatif (Principles of Quantitative Research Methodology), Edisi Pertama. Makassar: CV Indobis. pp. 80 (2003)

[6] Alie, A. A.: Nilai-nilai Demokrasi pada Empat Etnis di Sulawesi Selatan (Democratic Values at Four Ethnics in South Sulawesi). FIK-LSM: Yappika Sulawesi Selatan. pp. $82-84$ (1999)

[7] Rousseau, J. J.: Du Contract Social. Jakarta: Visimedia (2007)

[8] Ibrahim, A., Sulesana.: Kumpulan Essai Tentang Demokrasi dan Kearifan Lokal. (Sulesana: Anthology of Essays on Democracy and Local Wisdom). Makassar: Lephas. pp. 30. (2003)

[9] Hamid A.: Manusia Bugis Makassar (Man of Bugis Makassar), Jakarta: Inti Idayu Press. pp. 88 (1985)

[10] Badiou A.: Infinite Thought. London: Continuum. pp. 35-57 (2004) 